vol.4 No.1 - 2017

\title{
EFFECT OF NURSING GUIDELINES REGARDING INFECTION CONTROL PRECAUTIONS ON KNOWLEDGE OF NURSING STAFF IN SURGICAL UNITS AT GASTROENTEROLOGY CENTER. \\ ${ }^{1}$ Amany El-Sayed Mohamed Amer, ${ }^{2}$ Amany Mohamed shebil, ${ }^{3}$ Ahmed Mohamed Sultan, ${ }^{4}$ Hanan Abo Bakr \\ 1 Clinical Instructor, Gastroenterology Center, Mansoura University, 2professor of Medical - Surgical nursing ,Faculty of nursing, Mansoura University, 3 Assistant Professor of General surgery, Gastroenterology Center, Mansoura University 4Lecture of Medical - Surgical nursing ,Faculty of nursing, Mansoura University E-mail of the corresponding author: amany_amer00@yahoo.com
}

Abstract

Background: Hospital procured contaminations are a noteworthy trouble for all hospital staff. Knowledge of health staff about health services infection and its transmission with counteractive action can limit the spread of illness in health care institutions and in Society, so staff nurse must be instructed about fundamental standards of disease control and ability on the grounds that the nature of nursing consideration relies on upon a substantial degree on the learning. The aim of the present study was to investigate the effect of nursing guidelines regarding infection control precautions on the knowledge of staff nurse in surgical units at Gastroenterology Center Mansoura University. Methods: A quasiexperimental design was used .Tool: two tool were applied tool1: personal data of nursing staff such as: name, age, educational level, marital status, years of experience, tool 2: Nurses knowledge interview sheet include; hand hygiene, Personal protective equipment, handling sharp instrument, environmental hygiene, urinary catheter, caring of wound dressing, waste management . Results: The studied nurses age was ranged from 18-30 years, the most educational level among them was technical diploma, about their previous years of experience it was ranged from 4-6 years. The applied infection control guidelines were found to be highly effective, regarding nurse's knowledge. Furthermore, the differences between nurses knowledge were statistically significant post guidelines compared to pre, immediate. Conclusion: Applying the infection control guidelines improve nurses' knowledge and continues nursing education should be applied as policy or hospital standard this help in applying universal precaution well, so decrease hospital cost ,safe patient health, decrease hospital stay .

Key words: Infection Control, Precautions, Guidelines

\section{Introduction:}

Hospital procured contamination alludes to contamination that is obtained during performing patient's care and not show any signs or symptoms at recent time of hospitalization ${ }^{[1,2]}$. Around $5 \%-10 \%$ of hospitalized patients in advanced countries obtain infection any time, while the danger of gaining contamination is $2-20$ times higher in developing countries ${ }^{[3]}$.

It constitutes a worldwide medical issue, and is considered as one of the main sources of morbidity and mortality; longer duration of hospital / ICU stay; increased severity of the underlying illness; increased utilization of devices for monitoring and treatment; increased cost of treatment in both advanced and poor countries; and impedance of the nature of patient's and family's life [4]. HCAI accounts for higher rates of morbidity and mortality among critically ill patients, due to severity of illness and thus increased 
Amany El-Sayed Mohamed Amer et. al.

susceptibility to acquire more
microorganism ${ }^{\text {[5]. }}$

Infection control standards become an integral part of the accreditation program for all medical settings in Egypt, where the National Guidelines for Infection Control" are produced and established by a team at the Ministry of Health \& Population (MOHAP) since the year 2003. ${ }^{[6,7,8]}$.

Infection control standard precautions include certain measures such as hand hygiene, sharps safety, staff health, use of personal protective equipment (PPE), equipment safety, single use policy, waste management and environmental cleaning. Numerous contamination control measures, like suitable hand cleanliness and the right utilization of essential precautionary measures during any therapeutic managements are basic and of minimal effort, yet need staff responsibility with behavioral modifications, notwithstanding enhancing staff instruction, announcing and observation frameworks ${ }^{[9]}$.To use these precautionary measures, the healthcare team assumes an imperative part in expanding or diminishing the chances of catching hospital infections ${ }^{[10]}$.Therefore, sufficient staff nurse is important on the grounds that a higher patient-to nurse proportion builds the danger of nasocomial disease ${ }^{[11]}$.

Staff nurse are at the focal point of patient care and the social insurance experts well on the way to capture mistakes and forestall damage to patients, they can straightforwardly avert diseases by performing, checking, and guaranteeing consistence with aseptic work method; giving learned collective oversight on natural purification serve as essential asset to recognize and allude sick guests or staff; diminish the hazard for contamination and colonization utilizing proof based aseptic work hones ${ }^{[21]}$.Thus, nurses ought to get extra contamination control training and occasional assessments of aseptic care as an arranged patient safety activity ${ }^{[12]}$

Since nurses serve an imperative part in limiting the transfer of organisms in two ways, first, as the health experts who regularly invest the most time with patients; nurses have a huge opportunity for spreading organisms. It is basic that nurses purify their hands prior and after patient's contact and after performing a potentially hand infection action. The second way that nurses diminish hand-tohand spread is to serve as patient promoters with the quantity of social insurance specialist. In this way, the nurses are challenged in hand-hygiene to feasible the degree that ought to be seen during different activities with other professionals and discuss with them ${ }^{[13]}$

\section{Significance of the study:}

Compliance with universal precautions requires initial and refreshing courses for all staff regarding their knowledge and must be posted in a strategic location. Health care personnel need to be aware of the disease transmission cycle and the risks to which they are exposed. as health care personnel with a higher level of knowledge about universal precautions demonstrated a notably higher level of compliance than those who had a lower level of knowledge ${ }^{[14]}$

\section{Aim of study:}

The study aim was to: investigate the effect of nursing guidelines regarding infection control precautions on the knowledge of staff nurse in surgical units at Gastroenterology Center Mansoura University.

\section{Research hypothesis:}

Staff nurse whom applied nursing guidelines regarding infection control precautions will have improvement in their knowledge, score than those who don't.

\section{Methodology :}

Study Design:

A quasi-experimental design was used in this study. 
EFFECT OF NURSING GUIDELINES REGARDING etc ...

Setting:

Gastroenterology center is

affiliated to Mansoura University. This center has outpatient clinics, inpatient surgical department, theses department serving all patient admitted from outpatients clinic and who need surgical operation related to GIT system were performed in the center, affiliated to Faculty of Medicine, Mansoura University.

\section{Subjects:}

The sample of the study include all available number of nurses (50) and were divided alternatively into two equal groups 25 staff each as follows: Group I (study group) received infection control guidelines. Group II (control group) did not receive. The criteria for selection of the study samples: were (20-60) years old. all level of education ,agree to be involved in the study.

Tools:

Two tool were applied for data collection.

Tool I: socio-demographic characteristics of nursing staff such as: name, age, educational level, marital status, years of experience

Tool II: Nurses knowledge interview sheet; It was developed by researcher to assess the knowledge data about; infection control, hand hygiene, Personal protective equipment (gloves, mask, gown), handling sharp instrument, staff performance, visitors, environmental hygiene, handling laboratory specimen, safe injection practice, urinary catheter, caring of wound dressing and giving intravenous infusion. This questionnaire was applied either pre or post guidelines implementation.

\section{Methods :}

- Formal demand to lead the study was coordinated from the Dean of Faculty of Nursing, Mansoura University to the Head of gastroenterology center.

- The researchers met the authorized health care providers (physicians and nurses) in the study setting, explained the study aims, and methodology of data collection.

\section{Ethical consideration:}

- Prior to the study the researcher will be obtained the nurses' permission before conducting the research study and informing them about the confidentiality of information will be give along with the question.

- Verbal clarification of the aim and the nature of the work will be explained to nurses.

- The researcher accentuated that work involvement is completely and private

- Anonymity, security, wellbeing and privacy will totally guaranteed all through the entire study.

- Every member has the privilege to pull back from the study whenever

Validity \& reliability:

- An Expert Panel composed of 10exeperts in related fields (4 professors in surgical medicine in gastroenterology center, 2 professors in microbiology medicine, 4 nursing professors then the necessary modifications were done accordingly.

- Test reliability of interview sheet for nurse's knowledge was done by Cronbaches alpha test (alpha=0.061).

- Tool were developed.

Pilot study :

- A pilot study was carried out on five nurses (10\% of the study sample), before starting data collection. Accordingly, any modification was done to improve the study technique quality and efficiency. The nurses included in the pilot study were barred from the primary study aggregate.

- As soon as the study idea agreement was obtained, the guideline implementation were applied through 4 phase; assessment phase planning, implementation, evaluation phases.

- The nurses' knowledge were assessed through distribution of the study tool I 
which take 15-30 minutes, then infection control guidelines were developed based on nurses needs, previous related literature review, scientific journals.

- It contain theoretical component, which is applied within nurses' working hours they divided into small groups each sessions lasts 15-30 minutes, infection control nursing guidelines booklet was given to each nurse after sessions as a gift.

- Then evaluation was focused on estimating the effect of these guidelines on nurses knowledge through three point time pre, immediate and post

\section{Results:}

Table 1: clarify socio demographic data of research sample. It is clear that about $36 \%$ of study group their age were between 18-

30 years while the same age group in control group with different nurses percentage $(40 \%)$; as regard marital status nearly similar percentage $(56 \%, 60 \%)$ of studied nurses in both groups are married, the technical diploma is the most common educational level in both groups (44\%$46 \%$ ) respectively.44\% of study group. Their experience years was 4-6 while in control group .also $44 \%$ of them had $2-4$ years experience, regarding attending training course68\% of study group did not attend the course while $56 \%$ of control group had training course .

Table (1): personal data of the studied nurses $(n=50)$

\begin{tabular}{|c|c|c|c|c|c|c|}
\hline \multirow{2}{*}{ Characteristics } & \multicolumn{2}{|c|}{ study } & \multicolumn{2}{|c|}{ control } & \multirow{2}{*}{$X^{2}$} & \multirow{2}{*}{$\mathbf{P}$} \\
\hline & $\mathbf{N}$ & $\%$ & $\mathbf{N}$ & $\%$ & & \\
\hline $\begin{array}{l}\text { Age groups: } \\
\text {. } 18-30 \text { years } \\
\text {. } \quad 30-40 \text { years } \\
\text {. } 40-50 \text { years }\end{array}$ & $\begin{array}{l}9 \\
8 \\
8\end{array}$ & $\begin{array}{l}36 \% \\
32 \% \\
32 \% \\
\end{array}$ & $\begin{array}{l}10 \\
7 \\
8\end{array}$ & $\begin{array}{l}40 \% \\
28 \% \\
32 \% \\
\end{array}$ & 0.530 & 0.912 \\
\hline $\begin{array}{ll}\text { Education level: } & \text { Secondary } \\
\text { - } & \text { Diploma } \\
\text { - } & \text { Technical } \\
\text { Diploma } \\
\text { - } \quad \text { Bachelor }+ \\
\text { Master Degree } \\
\end{array}$ & $\begin{array}{l}7 \\
11 \\
7\end{array}$ & $\begin{array}{l}28 \% \\
44 \% \\
28 \%\end{array}$ & $\begin{array}{l}2 \\
16 \\
7 \\
\end{array}$ & $\begin{array}{r}8 \% \\
64 \% \\
28 \% \\
\end{array}$ & 0.4781 & 0.189 \\
\hline \begin{tabular}{ll} 
& \multicolumn{1}{c}{ Marital status: } \\
- & Single \\
- & Married \\
- & Divorced \\
& + Widow \\
\end{tabular} & $\begin{array}{c}7 \\
14 \\
4\end{array}$ & $\begin{array}{l}28 \% \\
56 \% \\
16 \%\end{array}$ & $\begin{array}{c}7 \\
15 \\
3\end{array}$ & $\begin{array}{l}28 \% \\
60 \% \\
12 \%\end{array}$ & 0.1701 & 0.637 \\
\hline $\begin{array}{lc}\text { Years of experience } \\
\text { - } & 2-4 \text { years } \\
\text { - } \quad 4-6 \text { years } \\
\text { - } \quad>6 \text { years } \\
\end{array}$ & $\begin{array}{c}9 \\
11 \\
5 \\
\end{array}$ & $\begin{array}{l}36 \% \\
44 \% \\
20 \% \\
\end{array}$ & $\begin{array}{c}11 \\
10 \\
4 \\
\end{array}$ & $\begin{array}{l}44 \% \\
40 \% \\
16 \% \\
\end{array}$ & 3.218 & 0.359 \\
\hline $\begin{array}{l}\text { Attending training } \\
\text { courses: } \\
\text { - } \quad \mathrm{Yes} \\
\text { - } \quad \mathrm{No}\end{array}$ & $\begin{array}{c}8 \\
17\end{array}$ & $\begin{array}{l}32 \% \\
68 \%\end{array}$ & $\begin{array}{l}14 \\
11\end{array}$ & $\begin{array}{l}56 \% \\
44 \%\end{array}$ & 0.764 & 0.382 \\
\hline
\end{tabular}


EFFECT OF NURSING GUIDELINES REGARDING etc ...

Table 2: show the significant change regarding the grand total knowledge score pre, immediate and post guideline implementation in the study group with $\mathrm{p}$ - value $=(<0.0001)$. and there is no statistically significant difference in the grand total knowledge score over time in the control group with $\mathrm{p}$ - value $=(0.179)$

Table (2): Grand Total Nurses knowledge score over time in both group (Friedman test)

\begin{tabular}{|c|c|c|c|}
\hline \multirow{2}{*}{ Parameter } & \multicolumn{3}{|c|}{ Study } \\
\hline & pre & immediate & Post \\
\hline Mean $\pm \mathrm{SD}$ & $64.5 \pm 6.8$ & $70 \pm 4$ & $84.6 \pm 7.5$ \\
\hline Median & 67 & 67 & 86 \\
\hline Minimum & 52.7 & 59.6 & 55.7 \\
\hline Maximum & 73 & 86.5 & 92.7 \\
\hline p & \multicolumn{3}{|c|}{$<0.0001 * *$} \\
\hline \multicolumn{4}{|c|}{ Control } \\
\hline & pre & immediate & Post \\
\hline Mean \pm SD & $57.9 \pm 3$ & $60.1 \pm 4$ & $59.6 \pm 4.3$ \\
\hline Median & 57.4 & 60.2 & 59 \\
\hline Minimum & 53.7 & 54.2 & 53.5 \\
\hline Maximum & 67.9 & 68.7 & 72 \\
\hline p & & 0.179 & \\
\hline
\end{tabular}

Table (2): showed that the grand total knowledge score (pre, Immediate, and post) has no significant correlation with any of the studied socio-demographic data (age group, education level, or experience years).

Table (3): Relation between total Knowledge scores and socio-demographic data

\begin{tabular}{|l|c|c|c|c|c|c|}
\hline $\begin{array}{l}\text { Demo- } \\
\text { graphic } \\
\text { data }\end{array}$ & \multicolumn{3}{|c|}{ rho* } & \multicolumn{3}{|c|}{ P } \\
\cline { 2 - 6 } & Pre & Immediate & post & Pre & Immediate & post \\
\hline $\begin{array}{l}\text { Age } \\
\text { group }\end{array}$ & -0.027 & 0.137 & 0.085 & 0.850 & 0.344 & 0.559 \\
\hline $\begin{array}{l}\text { Education } \\
\text { level }\end{array}$ & 0.095 & -0.182 & -0.139 & 0.514 & 0.206 & 0.335 \\
\hline $\begin{array}{l}\text { Experience } \\
\text { years }\end{array}$ & -0.213 & 0.146 & 0.108 & 0.138 & 0.311 & 0.456 \\
\hline
\end{tabular}

Figure (1): Clustered box plot for grand total knowledge score in the studied group

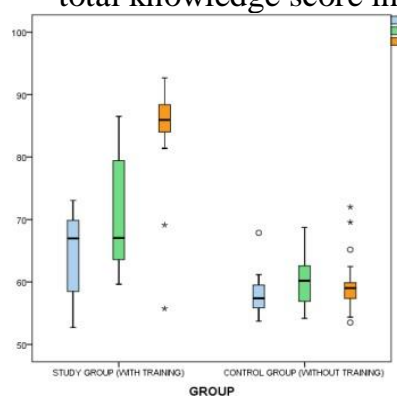

\section{Discussion:}

Infection prevention needs different approach. Infectious agents can be transmitted from their sources to a susceptible host by a lot of strategies, which involve health staff's hand contamination, on devices, and through airflow. The counteractive action of transmission by these methods can be routinely forestalled in healthcare settings utilizing ,standard safety measures ${ }^{\text {re }}$ which incorporate hand cleanliness and the utilization of individual protection devices 
when suspecting blood contact. Other methods of infectious agents transmission are by direct or indirect contact, mucous membrane infected with respiratory discharges.

our study findings revealed that the majority of the study ample were 18 to 30 years old .This matched with (Emanr.etal.,2012), who emphasized in her study that nurse's age was 23 years old, [15] and also with Dr. Imad. etal.,2015 in his study, he mentioned that about two thirds of the studied sample aged between 20 to 30 years old ${ }^{[16]}$ also in line with Neanaa., 2016 his result revealed that nurse's age were ranged between 20 to 39 years old. ${ }^{[17]}$

As regard education level, in our study the majority of nurse's educational level was technical Diploma, this was not in line with (Emanr.etal.,2012) he emphasized that large number of nurses in his work were secondary school. But On the contrary with Neanaa M., 2016 who reported that above $50 \%$ of nurses were bachelor degree this could be due to our low socioeconomic status community police in graduating nursery school and this help in further employment of theses nurses and reflect relation between little nurse's age and many years of working experience.

Regarding nurses' years of experience, our research results revealed that large number of nurse's job experience were 4 to 6 years. This was in line with Zanco et al 2014 in his study in which he mentioned that the highest proportion of nurses has job experience between one to five years, [19] but was not in line with Neanaa M., 2016 in a study revealed from that above $50 \%$ of nurses had less than 5 years of job experience This short period may render them in experienced in dealing with patient as, years of experience in any departments have a significant effect on the nurses' knowledge and practices which result in improving nurses" compliance with the optimum performance in all nursing aspects of their field generally despite if nurse performance specialized in one specific field like surgical units.

concerning, attending training courses; in our study the majority of studied nurses haven't attend training courses. this was in harmony with Imad ., etal 2015 who mentioned that about $66 \%$ of nurses did not attend any infection prevention training program. But not in harmony with, Neanaa M., 2016 who mentioned that the majority of studied nurses had previous training in infection control. And also with Sopirala et al.,2014 who stated in his study that, majority of nurses attained previous training program. This explain that learning is a basic component in the preparation of all health care staff especially in nations where there is a lack of formal and efficient disease control projects with insufficient resources in developing countries, like Egypt, still have to manage complex issues related to blood borne exposure and authorization of standard safeguards. what's more, might be because of lacking of inspiration and failure of some nurses to attend training sessions likewise they may feel that going to courses has no value for them and not and not influencing their pay.

present research consequences show that, the knowledge scores of study group nurses at surgical units post guidelines enhanced altogether in the quick post test. A conspicuous change in nurses post assessment total and subtotal knowledge scores were archived as compared to their pre assessment knowledge with large statistical changes. This change might be identified with the way that most of them are youthful, and have more than five years experience in this respect (Abou Elela,2008) who studied adequacy of nursing care facilities and its effect on nurses infection control behavior $\mathrm{El}$ manila university hospital master thesis, he mentioned that ,knowledge may be easily 
gained but performance needs facilities ,supplies and equipments to be perfect. [20 On other hand (Bauwens, 2002) mention that infection control concept translates knowledge into action ; it incorporates development and maintenance of an attitude of awareness of infection with acceptance of individual and collective responsibility to prevent infection [21]

These findings in agreement with Sersg 2008 study "Impact of designed training program on nurses knowledge, practice and on patient out come at the Intensive Care Unit, Benha University Hospital, who reported an improvement in nurses" knowledge scores post guidelines [22] Also agrees with Taha,2004 who reported an improvement in nurse's knowledge scores post guidelines with a highly obvious changes. ${ }^{[23]}$,also Seada 2003 document a significant increase in nurse's mean knowledge scores immediately after guidelines contrasted with pre knowledge scores. ${ }^{[24]}$

Concerning nurses" knowledge about the infection control concept, there was much significant changes pre ,immediate and post test knowledge .this is potentially on the grounds that they didn't get enough information or practical training.

our study revealed that the grand total knowledge score (pre, Immediate, post and 4weeks post) has no significant correlation with any of the studied socio-demographic data (age group, education level, or experience years), on the other hand, Zatton $\mathbf{2 0 0 3}$ in his study notify a positive relation between nurses ${ }^{\text {ee }}$ knowledge and years of experience[25]

Avoidance of contamination is an essential viewpoint for nurses in their clinical field and are coordinated to recognize the disease control components of this clinical practice. This incorporates however is not constrained to give safe system that ought to be begun, and finished utilizing an aseptic procedure to minimize the harmful founding of exogenous living beings for surgical

patients.

Conclusion:

Applying infection control precautions guidelines helps greatly in improving nurses knowledge and thus further improve their performance when caring patients this also indicate the important need for putting nursing continuous education and training hospital policy which reflect on patient health and save cost \&time of his stay in hospital Recommendation:

Based on the results, study recommendations are:

- Administrators ought to make strategies and arrangements for giving consistent instruction to the nursing staff

- The educational program regarding each items of infection control universal precautions should be for newly and old employed nurses

- Organizing periodically check up system for nurses in hospital.

- Regular virology test and great attention for $\mathrm{HBV}$ vaccine for nurses and providing suitable treatment in any suspecting of infection.

Acknowledgments:

I would like to thank all nursing staff and the head of the Gastroenterology Center, Mansoura University, as it would not have been possible to complete this work without their valuable contribution, cooperation and support.

\section{References:}

1. Boyce, M.J. and Pittet, D. (2002). Guideline for Hand Hygiene in Health Care Settings. Recommendations of the Healthcare Infection Control Practices Advisory Committee and the HICPAC/ SHEA/APIC/IDSA Hand Hygiene Task Force.http://www.cdc.gov/mmwr/prev iew/mmwrhtml/rr5116a1.htm 
2. Vandijck, D., I. Cleemput, J. Hellings and D. Vogelaers, 2013. Infection prevention and control strategies in the era of limited resources and quality improvement: A perspective paper. Australian Critical Care, 26: 154-7.

3. Agency for Healthcare Research and Quality (AHRQ). (2009). OnTime Quality Improvement Manual for Long Term Care Facilities. Available from: http://www.ahrq.gov/research/ltc/onti meqimanual/qimanual1. $\mathrm{htm}$ (accessed December 2011).

4. Donegan NE (2014) Management of Patients with Infectious Diseases: Brunner \& Suddarth's Textbook of Medical-Surgical Nursing. 10th ed., Mosby/Elsevier, New York, p.p. 21152122.

5. Satekge, M. M. (2010).Knowledge, attitudes and practices regarding the prevention of hepatitis $B$ virus infections in final year college student nurses in Gauteng province (M.Sc. Thesis). Medunsa: School of Public Health, University of Limpopo.

6. Gould DJ, Drey NS, Moralejo D, Grimshaw J, Chudleigh J. Interventions to improve hand hygiene compliance in patient care. Journal of Hospital Infection 2008; 68: 193-202.

7. El-Kholy A, Saied T, Gaber M, Younan M, A. Haleim M, El-Sayed H, El-Karaksy H, Hafez Bazara'a H and Talaat $m$ (2012): Deviceassociated nosocomial infection rates in intensive care units at Cairo University hospitals: First step toward initiating surveillance programs in a resource-limited country. American Journal of Infection Control 2012; 40 e216-20 e217

8. Hughes RG Patient Safety and Quality: An Evidence-Based Handbook for Nurses: Agency for Healthcare Research and Quality, $U$.
S. Department of Health and Human Services, 540 Gaither Road, 2008, Rockville, MD 20850. Internet accessed at February, 2014..

9. Saleem, T. (2010). Knowledge, attitudes and practices of healthcare personnel regarding needle stick injuries. Journal of Pakistan Medical Association, 60(2):151-6. Retrieved on March 20, 2010 from http://www.ncbi.nlm.nih

10. Tracey B. Peripheral cannulation: A practical guide. Br J Cardiac Nurs 2010;5(3):124-31.

11. National Health and Medical Research Council: Australian Guidelines for the Prevention and Control of Infection in Healthcare (2010). Canberra Canberra: National Health and Medical Research Council; 2010.

12. Siegel JD, Rhinehart E, Jackson M, Chiarello L: 2007 Guideline for Isolation Precautions: Preventing Transmission of Infectious Agents in Health Care Settings. Am J Infect Control 2007, 35(10 Suppl 2):S65S164

13. EMAN R. AHMAD, D.N.Sc.; MERVAT KHAMIS, D.N.Sc.; ENTISAR M. YOUNIS, D.N.Sc. and SAFWAT A. ALRADY, M.D.

Effect of a Developed Educational Booklet about Standard Infection

Control Precautions on Nurses' Knowledge and Practices at Woman's Health Center-AssiutUniversity Hospital, Egypt Med. J. Cairo Univ., Vol. 80, No. 1, September:435445,2012

www.medicaljournalofcairouniversity. com

14. Dr. Imad Fashafsheh Mr. Ahmad Ayed* Mrs. Faeda Eqtait Mrs. Lubna Harazneh, Knowledge and Practice of Nursing Staff towards Infection Control Measures in the Palestinian Hospitals,Journal of 
Education and Practice www.iiste.org ISSN 2222-1735 (Paper) ISSN 2222288X (Online) Vol.6, No.4, 2015

15. Neanaa M., Fayed, 2Hanan T., Elbahnasawy, Taghreed K., Omar (2016), Effect of Instructional Program on Nurses Compliance with Universal Precautions of Infection Control. International Journal of Novel Research in Healthcare and Nursing Vol. 3, Issue 1, pp: (81-92), Month: January-April 2016, Available at: www.noveltyjournals.com

16. Hany Girgis Eskander Journal of Education and Practice www.iiste.org ISSN 2222-1735 (Paper) ISSN 2222288X (Online) Vol.4, No.19, 2013

17. Zanco J. Med. Sci., Effect of an educational program on nurses' knowledge and practices toward Hepatitis $B$ virus in emergency hospitals in Erbil City Vol. 18, No. (1), 2014

18. Abou Elela,T.H., (2008): Adequacy of nursing care facilities and its effect on nurses infection control behavior during antenatal and post natal care , maternity hospital EL-Manial university hospital master thesis faculty of nursing Cairo

19. Bauwens 2002 :Evaluation of a training programme on knowledge and compliance of nurse assistants hand hygiene in nursing homes. Journal of Hospital Infection 2002;68:164-70.
20. Serag,H ,A (2008): Ventilator associated pneumonia: Impact of designed training programion nurses knowledge, practice and on patient out come at the Intensive Care Unit, Benha University Hospital, Doctorat, Thesis, Faculty of Nurses, Benha University

21. Taha FA. Impact of Universal Precautions Training on Nurse Midwives Knowledge, Attitude and Practices toward Prevention of HIV Transmission in Khartoum State. Teaching Hospitals, 2006-2009, Faculty of Nursing Sciences University of Khartoum. Available at www.davidpublishing.com/DownLoad /?id=16733. Internet accessed at November, 2014.

22. Seada, A.M. (2003): Effects of a training program on staff nurses performance and empowerment in the emergency unit at El manial university hospital, A thesis submitted for the doctorate degree in medical surgical nursing, faculty of nursing, Cairo university, pp (121-123).

23. Zatton HK. Impact of implementation of health education program in improving nurses' knowledge and performance about care of viral hepatitis patients admitted in Zigzag University Hospital. Doctorate Thesis, Faculty of Nursing. Zigzag University, Egypt 2007. 